\title{
DRAFT
}

Submitted to the 1st International Congress of Qualitative Inquiry, May 5-7, 2005 University of Illinois at Urbana-Champaign

Session: Cultural Studies, Education and Pedagogy: I, Friday, May 6, 2005 11:45-1:15, Room: Union 211

\section{The Culture of Discourse on Educational Reform in Spain}

\section{Cathryn Teasley}

Departamento de Pedagoxía e Didáctica das Ciencias Experimentais

Facultade de Ciencias da Educación

Universidade da Coruña

Campus de Elviña, s/n

15071 A Coruña, Spain

cathryn@udc.es 


\title{
The Culture of Discourse on Educational Reform in Spain
}

\author{
Cathryn Teasley \\ Departamento de Pedagogía y Didáctica de las Ciencias Experimentales \\ Facultad de Ciencias de la Educación \\ Universidad de A Coruña \\ Campus de Elviña, s/n \\ 15071 A Coruña, Spain \\ cathryn@udc.es
}

Please Note: For quotations and reference purposes, please refer to a nearly exact version of this essay that has been recently published in The Review of Education, Pedagogy \& Cultural

Studies, 26(4), October-December 2004, pp. 249-275.

\begin{abstract}
This essay examines the role that educational reform discourse has played in addressing the needs of increasingly culturally diverse student populations in Spain. The reforms initiated earlyon in the post-dictatorship period produced some promising shifts in the official narratives on the culture of schooling in Spanish society, but no sooner had the most far-reaching of such policies been fully implemented, than a conservative counter-reform was crafted to overturn some of its more substantive tenets. That intention has nonetheless been halted by the recently elected Socialist Party administration, which is developing yet another reform. As policy makers thus battle over the ideological control of education, what have poor immigrant and Roma students actually stood to gain in the process? This paper aims to reveal the construction of the cultural Other through such rivaling discourses on education, and to suggest some ways to destabilize their most stable of undercurrents
\end{abstract}

\section{Introduction}

Where the education of subaltern multicultural student collectives is concerned, the case of contemporary developments in the discourse of reform in Spain is particularly poignant. A critical engagement with that discourse and its greater sociocultural context reveals some of the subtle ways in which cultural alterity comes to be represented. And because the implications for 
immigrant and Gypsy/Roma ${ }^{1}$ groups are serious and complex, such representations can and must be challenged on multiple fronts, some of which are pursued in this essay.

Before embarking on that task, however, it should be pointed out that the main focus here is on the production of policy discourse as opposed to the actual pedagogies occurring in schools. This focus has been chosen even as it becomes clear that, in Western educational systems, inequality persists despite the ebb and flow of most "top-down" reform efforts - as researchers from analytical camps both radical (Apple, 1996; Martínez Bonafé, 1998) and postmodern (Popkewitz, 1991; Varela \& Álvarez Uría, 1991) have observed. Given this reality, why then engage the discursive realm of reforms? Official narratives on education are called into question here for the same reason that the gap between theory and practice must be bridged, for, policy discourse - as a cultural construct — is in fact generated at various points along the theorypractice continuum. But the power it exerts on educational phenomena is highly relative and heavily conditioned along the way.

In this Foucauldian sense, official pedagogical knowledge, as relayed through the discourse of reform, is not only historically contingent, but coexists and competes with other regimes of truth. These include "common sense" versions of professional knowledge, or "the wisdom of experience" in teaching (Popkewitz, 1998), as well as teachers' reliance on the security of routine and the economy of effort (Eisner, 1992), or on ritual performance (McLaren, 1999). Moreover, whereas the oft-cited impetus behind reforms is to democratize schooling, administrative structures and processes are likely to place educators in "the uncomfortable region where ideas of bureaucracy and democracy confront one another" (Kemmis, et al., 1987, p.337), and where institutional situatedness or the very "regions of culture" (Bennett, 1992) influence any agency involved in both producing and applying reform policies. But perhaps the most 
challenging of all these tensions is the fact that, as shall become clear in this paper, reform policies themselves — as cultural technologies and forms of social regulation — are wrought with countervailing ideologies which further undermine the surface aims of reform, and instead tend to support the status quo of political power (Apple, 1996; Popkewitz, 1991). Inevitably, then, policy discourse is implicated in struggles for power. This in part embodies what Stuart Hall (1996) has referred to as the "ideological effect" of discourse. The problem therefore does not lie in whether such discourse exerts power in diverse realms of social practice, but in the ways and the extent to which it does.

In what follows, the ideological effect of the dominant discourse of reform is examined in the context of the educational institution of Spain. Specifically, the dual aim will be to uncover, on the one hand, the most pervasive representations of cultural otherness in recent reform legislation, and to explore, on the other, the potential effects (or power) of such representations on both historically oppressed, and more recently settled multicultural student populations. The notion of "nonsynchronous" sociocultural dynamics (McCarthy, 1990), as well as Nietzsche's concept of "resentment" in cultural identity formation and representation — as further developed by McCarthy \& Dimitriadis (2000) — will largely inform this endeavor. And in order to properly situate this policy discourse, its content will be analyzed by way of two major reform laws, as well as through mass media coverage of educational policy issues, recent school-related controversies, and other social developments in Spain and beyond. Morley and Robin's (1995) insights regarding the global/local nexus of identity formation, among others, will guide the analysis in this more general sense.

On a final note, our attention will be drawn to the pursuit of crosscultural justice through the democratic production of educational discourse. To this end, we shall examine the ways in 
which several scholars aim to promote a more participatory and inclusive democratic process, as initiated from both within and outside of the educational institution. These include Seyla Benhabib's (1992) notion of "interactive universalism" for deliberation in the public sphere, as well as various insights on schooling for a democratic society, from scholars whose works reflect the educational philosophy of John Dewey, among others. These complementary perspectives, when coupled with a series of critical pedagogical strategies, hold promise for disrupting the biased production of discourse that resonates throughout reform policies.

\section{Cultural Representation in the Discourse of Reform}

\section{$\underline{\text { Situating the Discourse }}$}

To understand the broader socio-political context from which a series of reform movements emerged in Spain during the 1980s and early 1990s, of primary importance is the country's formal transition in the late 1970s from a dictatorship to a parliamentary monarchy. With the promulgation of the Constitution of 1978, the linguistically diverse, cultural and political geographies of the seventeen historically differentiated "regions" of Spain — including Catalonia, Galiza (or Galicia), the Basque Country, and Andalusia, among others - were transformed into "Autonomous Communities" and endowed with specific forms of political autonomy from the central State government based in Madrid. Thus, educational administration is now almost entirely a competency of the autonomous governments. ${ }^{2}$

The Socialist Workers Party majority government of the post-transition period (19821996) proceeded to institute a number of educational reforms that would reconcile the educational system with these new civic and educational rights and responsibilities. The most 
comprehensive of such reforms is known as the LOGSE of 1990 (translated as the Organic Law for the General Ordering of the Educational System), ${ }^{3}$ and will constitute the object of much of the analysis that follows. Another significant political event of the 1980 s included the formal incorporation of the Spanish State into the then European Economic Community (full membership was attained in 1986). That development has since entailed an ongoing process of economic, political and cultural recontextualization in Spain, which has in turn been paralleled by growing influence from the global economy and communications network — all of which have come to inform the discourse of educational reform in significant ways.

In conjunction with these dynamics, a relatively sudden confluence of new student collectives began to participate in Spanish schooling. That is, since the latter half of the 1990s, the country's traditionally higher emigration rates have fallen off and are now overshadowed by immigration - a reality reflected in the schools. According to recent estimates, immigrants now represent over three percent of the total population of Spain (de Lucas \& Torres, 2002). However, in a growing number of public schools servicing communities with relatively high concentrations of immigrants (especially in Madrid or Barcelona), such children have come to represent the overwhelming majority of students. ${ }^{4}$ Further, when the LOGSE's Compulsory Secondary Education was fully implemented in 1998, Gypsy or Roma students began to enroll in secondary education in more significant numbers. Under the former system, these students rarely attended high schools. ${ }^{5}$ Even so, the Roma population of Spain is estimated at approximately three quarters of a million, or two percent of the total. ${ }^{6}$

While the intent here is not to homogenize - as Homi Bhabha (1994) warns is most often the case — the diverse and ever-changing cultures, histories and educational needs of different subaltern groups, the various Gypsy and immigrant student collectives of Spain do share at least 
four important characteristics that are central to our analysis. The first relates to the fact that the great majority are of the popular classes and have experienced important degrees of poverty and marginalization (de Lucas \& Torres, 2002; San Román, 1997). A second shared characteristic concerns these groups' linguistic heterogeneity, which is overwhelmingly subordinated to the Castilian, and, to a lesser degree, to the other official languages of Spain. For example, some Gypsy collectives - with the exception of those recently immigrated from Eastern Europe, or those of Iberian background whose dominant languages include varieties of Catalan, Portuguese (including Galizan), or other Iberian languages — still speak a Romani-based variety of Spanish called caló, albeit in ever-decreasing numbers (Courthiade, 1998). The likely disappearance of the calo is undeniably due to the long-term effects of historic persecution in Spain and Europe of speakers of Romani, the root language of the Gypsy diaspora (Liégeois, 1998; Torrione, 1994) A serious repercussion of such oppression is that the Roma have until very recently been unable to develop their own literary tradition. This cruel legacy represents, as Fernández Enguita (1999) points out, one of the most enduring injustices affecting the education of the Gypsy people today.

As for the numerous home languages of immigrant students (of which various sectors of the Gypsy population are also constitutive), specific language-maintenance programs have been developed for Arabic- and Portuguese-speakers, these being the two largest non-official language groups within the State educational system. However, they are allotted on a provisional, piecemeal basis, and in most cases are extracurricular or comprised of homogeneous groupings. A growing number of researchers and educators are therefore demanding that such programs be more globally guaranteed and adequately integrated as vehicles of instruction in mainstream schooling (see Franzé Mudanó \& Mijares Molina, 1999; García Castaño, Granados Martínez \& García-Cano Torrico, 1999; or Morales 1999). 
A third feature common to both immigrants and Roma is that their respective ethnic identities differ from those commonly alluded to in the "cultural diversity" of Spain (i.e. the various ethno-linguistic and nationalist identities of the Autonomous Communities). As we shall see, this difference is manifest in the legislation in various ways. But the fourth and not least important shared characteristic is that people of immigrant or Gypsy origins are often the target of varying degrees of ethnocentric and racist discrimination from majority populations, not to mention growing xenophobic and racist violence (see for example Calvo Buezas, 2000 or San Román, 1997). A series of tragic incidents reported in the Spanish mass media from 1999 to 2002 further attest to this reality, the primary victims of which have been immigrants from the Maghreb (Morocco, Algeria, Tunisia). In Catalonia, for example, neo-Nazi groups mugged individuals, vandalized several homes, and burned down a mosque in one town, while elsewhere, the construction of a mosque was widely protested. In Andalusia, violent rioters attacked migrant workers following a local murder case (in El Ejido); and in another Andalusian town (Huelva), 7,000 Maghrebi migrant workers arrived to find a large part of their seasonal livelihood abruptly occupied by mostly eastern European women fieldworkers - themselves underpaid and less organized.

Where educational settings are concerned, the conflicts have been no less grave: In May of 2000, in the town of Barakaldo (the Basque Country), the first-time enrollment of three Gypsy children at a private primary school was angrily protested by most of the school's parents, some of which aggressed upon school personnel. Similar protests occurred in 2000, in Ceuta (an autonomous Spanish city and territory located along the Moroccan coastline), when thirty previously unschooled adolescents of Moroccan origins were to be "integrated" at a secondary school there, albeit in segregated groupings and after school. The following school year they 
were removed to a separate institution. And in yet another incident occurring near Madrid in February of 2002, a Moroccan teenager was told at one high school that she could not attend class if she wore her hijab or chador scarf. After re-enrolling at another school, the administrators there also discouraged her from wearing the scarf. Eventually, however, educational authorities established her right to attend school regardless of the hijab (this case will be addressed in further detail in the pages to come). All these incidents were given extensive coverage in the Spanish mass media.

Yet, while these dramatic events represent a fairly recent trend in Spain inasmuch as immigrants are concerned, such hostility is not new to the Roma people. They have suffered xenophobic and racist marginalization, aggression — even historic genocide missions — that date back to their arrival on the Iberian Peninsula in the fifteenth century (Asociación Presencia Gitana 1991) According to the advocacy group Asociación Secretariado General Gitano (2000), seventy percent of Roma are semi- or non-schooled, and most of those regularly schooled have experienced significant levels of academic failure. What is more, in an extensive study on the integration of Gypsy culture in schooling, it was found that Roma children tend to suffer the lowest social status of all culturally-subordinated student groups (Fresno García, 1994). A more recent study corroborates this conclusion, having discovered that majority-culture school children in Spain tend to represent Gypsy people in ways more stereotypical and negative than they do immigrants "of color" (Jover \& Reyero, 2000). This being the tragic case for Roma youth, the fact remains that, since the mid 1990s, immigrant presence in Spanish schools has increased substantially, as has a specific practice amongst dominant-culture parents: that of steadily removing their children from public schools that receive relatively high numbers of either Gypsy or immigrant students, as well as majority-culture youth of lesser economic means (Fernández 
Enguita, 1999; Gómez Llorente, 2000; Torres Santomé, 2001). As we shall see in the next section, post-transition Spanish educational legislation may have in fact facilitated this form of $d e$ facto segregation (also referred to as "white flight" in the US context).

Given, then, this troublesome sociocultural landscape in Spain, how are these diverse groups actually reflected in the discourse of the reforms instituted during the Socialist administration?

\section{The LOGSE}

As stated, the most broadly based and ambitious of the two reform laws under consideration is the LOGSE of 1990. No sooner has it been fully implemented, however, than it has recently been significantly amended by the Quality in Education Act - a conservative counter-reform approved in Parliament in December of 2002, for implementation during the 2003-2004

academic year. ${ }^{7}$ This latter reform law will be discussed in detail ahead, but what is most important for now is that the former LOGSE introduced a series of institutional reforms designed, according to its authors, to transcend the mere rhetorical or surface level of reform and to create a broader base for participation and opportunity in schooling (Fundación Hogar del Empleado, 2000).

The most important of the LOGSE's initiatives has been the two-year extension of compulsory, comprehensive education, from the long established age of fourteen to age sixteen. Other noteworthy changes introduced with the LOGSE include the establishment of an ambitious Early Childhood Education for ages zero to six, as a pre-compulsory level of the public education system, and the creation of new cross-curricular contents and pedagogical adaptations pertaining to democratic values and ethics. Further LOGSE innovations have included the establishment of 
counseling departments and tutoring periods; the reduction of both class size and the number of retentions permitted; and the application of new compensatory and special education measures. All of these innovations are meant to promote equal opportunity in the education of students "from unfavorable contexts" (Article 63), as compared to an implied, but unspecified idealtypical student population (who, we can assume, benefits from favorable home contexts). Given, then, these declared reforms and goals, how indeed are students representing both this ideal-type and the cultural Other(s) sifted through this ambitious piece of legislation?

\section{Linguistic Diversity and Representation of the Cultural Other}

Notwithstanding the Iberian Peninsula's traditional linguistic diversity, the cultural setting at the LOGSE's inception (in the 1980s) was characterized by a relatively high level of homogeneity, insofar as it is compared with today's rapidly growing immigrant presence in Spain. It may therefore come as no surprise that this "forward-looking" law (as described in its Preamble) indirectly defined the average student primarily through three, key, cultural, political and economic spaces: the nation-state, through the "citizen" figure; the Autonomous Community, in recognition of regional cultural diversity; and Europe, as the international community par excellence for the discourse on progress in the law. This Eurocentric crosscultural orientation is made further evident by the fact that the European Community is referred to no fewer than seven times in the LOGSE's Preamble, while no references are made to other continents.

The three tiers of hegemonic identity and representation described above become particularly salient in the LOGSE's treatment of linguistic diversity. Castilian Spanish — as the dominant, State language — is not only identified as the required object of study for all students, but also as the medium of instruction for over half of the instructional time allotment. Only after 
Spanish, are the "co-official languages" of Spain (such as Galizan, Basque and Catalan) also identified as both objects of study and the media of instruction in those Autonomous Communities where they are regulated (see Article 4.2 of the LOGSE). The only other languages specifically referred to in this law pertain to the cultural realm of Europe, and include the "Foreign Languages" (such as French, English or German) and the languages of "Classical Culture" (Greek and Latin). This linguistic hierarchy thus suggests that the LOGSE was designed first for Spanish speaking students, then for those speaking the "autonomous" languages of Spain, and then perhaps even for "foreign" students, but much less for "immigrant" students (to reflect a popular distinction). Despite this form of exclusion, native-Arabic speakers now constitute the country's largest non-Spanish speaking linguistic group among immigrants. ${ }^{8}$ And whereas the aforementioned Arabic- and Portuguese-language educational programs have existed since the 1980 s, the right to such instruction is not guaranteed in the LOGSE.

As for speakers of caló, their specific linguistic rights and needs in learning are not directly addressed either in the LOGSE. Yet, where some sectors of the Gypsy student population do still speak caló, they have been found to run up against a linguistic disadvantage vis-à-vis the Castilian standard used in schooling (Bueno Aguilar, 1993). Not surprisingly, however, the few well-intended initiatives presented by non-Gypsy educators to promote the use of caló in schooling, have been met with ambivalence from Gypsy families: These fear that such programs might lead to a new means of segregating their children from mainstream schooling — as turned out to be one of the unintended outcomes of the former "bridge schools" of the 1980s, located in or near Roma communities (see Asociación Secretariado General Gitano, in Fernández Enguita, 1999). The complexities of this issue, however, should not lead to an evasion of the role that this dialectal variety can potentially play in promoting more equitable learning and crosscultural 
understanding between and among Roma and payo (non-Gypsy) students, in heterogeneous classrooms. This point is especially relevant considering that the effective acquisition of the power-standard (such as Castilian Spanish) may be better achieved through the formal recognition and constructive use of non-standard varieties - an argument sustained in the case of using Ebonics, or African American Vernacular English, in US schooling (see Perry \& Delpit et al., 1998; Williams, 1991). Related arguments have been made to promote the integration of varieties spoken by members of subordinated social classes as well (see Bernstein, 2000).

Returning to the LOGSE, these linguistic concerns are crucial if mere access to equal opportunity in education is to truly be a right. Indeed, the LOGSE claims that:

The educational Administrations will ensure preventive and compensatory action, thus guaranteeing, in each case, the most favorable conditions for schooling, during Early Childhood Education, for all children whose personal conditions — due to low family income, geographic origin, or whatever other circumstance - constitute initial unequal access to compulsory education and subsequent levels of learning (Article 64; italics added).

Yet how can these "most favorable conditions" be guaranteed if the children's first languages are not even acknowledged in this most basic of laws? International scholars on linguistic issues in education (see Skutnabb-Kangas, 2000) have long argued that ethnically diverse students' home languages must be recognized, respected and engaged in both legislation and schooling if socially just access to the curriculum and to the language of power - not to mention the development of self-esteem - is to become a reality. Considering that, on the one hand, Roma youth experience some of the highest rates of school failure in Spain (Fernández Enguita, 1999), and that, on the other hand, academic achievement amongst poor immigrant youth has been falling behind that of their majority-culture peers (Juliano, 1993); ${ }^{9}$ the omission of explicit reference in the LOGSE to the linguistic needs of these "Other" students is no less than tragic.

\section{Cultural Diversity Goes as Far as Europe}


Beyond linguistic factors, however, there is a firm insistence in the LOGSE on moral values centered around "peace, cooperation and solidarity" (Article 1g); "democratic coexistence" (Preamble); "mutual respect" (Preamble); "the struggle against discrimination and inequality" (Preamble); and — more controversially — "tolerance" (Article 19d). But this intentionally progressive discourse has been met with challenges both ongoing and recent. On the one hand, conservative legislators have considered the law to be in many ways too open - thus the counter-reform. On the other hand, since the LOGSE's inception, educators (at all levels), activists and legislators from the political left have asserted that middle class values and neoliberal, technocratic regimes of truth prevail in this law (see, e.g. Angulo Rasco, 1995 or Torres Santomé, 1992, 2001). To add to these latter critiques, we have seen that the LOGSE also fails to prove entirely open to cultural influences that transcend the imaginary of Europe or the West.

What is more, if the "tolerance" cited in the LOGSE is indeed a goal for Spanish society, who should be tolerating whom? And from which implied cultural vantage point? As Blommaert and Verschueren (1998) have argued, the act of tolerating assumes the subject's positioning heror himself within a predetermined, essentialized cultural realm — one not characterized by the realistic "hybridity" of human cultures (Hall, 1992); one which is not necessarily open; one that does not need to respect or embrace (but merely bear with) the perceived cultural Other. Tolerance therefore does not necessarily represent the most positive means by which crosscultural justice may be attained. Further, if we situate the discourse of educational reform within the greater cultural politics on immigration in Spain, we can perceive similar contradictions. While "controlled immigration" is not only justified but encouraged by today's 
right-wing government officials as necessary for the country to maintain current rates for State retirement, healthcare and unemployment benefits, the educational needs of immigrant populations are either barely hinted at in the basic education legislation (as we have so far observed in the treatment of linguistic diversity in the LOGSE), or they are presented as a problem, as will become evident in our analysis of the Quality in Education Act.

But before addressing this latter reform law, some additional European or Western cultural biases can be perceived in the LOGSE's discourse. For example, in the Titles covering basic curricular content, the references to culture have a monocultural slant: "Knowing the beliefs, attitudes and basic values of our tradition and cultural heritage" (Article 19h); or "acquisition of the basic cultural elements" (Article 12); or "transmitting to all students the basic elements of culture" (Article 18). This culture-in-the-singular (la cultura) remains undefined in the law, and therefore alludes by default to a set of hegemonic selections and representations of phenomena that are construed as those most worthy of study in the cultural practices of schooling. Clearly, this "use of culture" (McCarthy, 1998) in the LOGSE is not a de-centered one, and thus stands to be challenged from the margins. In the meantime, still other contradictions undermine this reform law.

\section{Mapping the Socioeconomic Trail of Reform}

The aim here is not to discredit the best intentions in the LOGSE for, as a reform, it may be considered as one of the most concerted efforts to democratize schooling in Spain. Even so, the intent is to reveal some of the countervailing forces that weaken the law's manifest progressive discourse. Consider Article 65.3 from "Title Five on the Compensation of Inequality in Education": 
Without compromising that stipulated in Chapter Five of this Law, the educational Administrations will endow school sites whose students experience special difficulty in attaining the general objectives of a basic education due to their social conditions, with the human and material resources necessary to compensate the situation. The instructional organization and planning at these sites will adapt to the specific needs of the students (emphasis added).

Upon close inspection of this discourse, it becomes apparent that the highlighted segment rests on the supposition that the standard ("a basic education") set by the institution is the primary point of reference — not the needs of students who, "due to their social conditions", are represented as some kind of Other vis-à-vis an unspecified, normative student body whose "social conditions" do not present difficulties in attaining a basic education. At issue here are the ideological implications embodied in the selfsame notion of "compensation", premised on some students' inability to adapt to the system — as a structure that is otherwise thought to be appropriate and relatively stable (Connell, 1993). Granted, the need for institutional adaptations are acknowledged, but they are to be addressed as exceptions to the rule - a rule that in fact prevails in education as a world institution (Ladwig, 2000). How then does this work to the detriment of those students designated as the recipients of compensation (e.g. Roma or immigrant youth)?

To begin with, it denies the reality that such youth do constitute the majority of the student body at some schools. That is, many "ghetto schools" have emerged of late, due in large part to a neoliberal bias at work in the LOGSE - a bias that serves the needs and demands of the more privileged social classes to whom schooling has traditionally responded (Varela \& ÁlvarezUría, 1991). It has emerged from a kind of symbiotic relationship between privatization and religion, which was formalized in 1985. At that time (less than a decade after the dictatorship), the greatly expanded public education system required numerous new schools, and in order to meet that urgent need, the Socialists instituted the "concerted" school regime. This program entailed the public funding of private schools that fulfilled specific infrastructural, organizational 
and curricular requirements, such as not charging tuition fees, or observing the same enrollment procedures required of any public school. The concerted school scheme was justified in the Organic Law on the Regulation of the Right to Education (Ley Orgánica de la Regulación del Derecho a la Educación or "LODE" of 1985) in terms such as the following:

Title IV likewise regulates the concerted school regime, which effectuates the public maintenance of private concerted schools that, together with public schools, contribute to making the right to free education efficient... (Preamble).

As it turned out, most private schools in Spain indeed participated in the program, and the majority of such institutions were also Catholic. That reality, however, roused only limited controversy both then and now, as today's concerted system is stronger than ever.

The reasons for this state of affairs are many, but perhaps one of the most evident can be found in the selfsame Constitution of 1978. Its Article 27.3 reads, "The public powers guarantee parents the right for their children to receive religious and moral education in accordance with their own convictions" Religious instruction has subsequently always been an option in posttransition public schooling, but never an imposition. Such has been the case even though a 1979 agreement between the Spanish State and the Vatican stipulates that "[t]he curriculum must necessarily include the teaching of the Catholic religion and, moreover, this must be taught at schools in conditions comparable to those of the other basic subjects" (see Lezcano López, 2000, p. 249). The Constitutional safeguard against the imposition of such doctrinal instruction in concerted schools has nonetheless done little to impede a kind of religious bias operating throughout the concerted regime (which will be explored in further detail below). Moreover, concerted schools are notoriously (and illegally) selective, and are known to charge "voluntary" service and admission fees (Torres Santomé, 2001). But most importantly, the LOGSE failed to challenge this scheme - a reality that has facilitated the proliferation of privately owned but 
publicly funded learning institutions, often to the detriment of nearby public schools. In effect, children who do not fit the dominant, middle class and Catholic cultural mold stand to gain very little from this de facto form of economic segregation and indoctrination in public schooling. In this way, the LOGSE indirectly reproduces school segregation by condoning the concerted system — a situation that becomes particularly troubling when considering the long history of segregation of Gypsy children from mainstream schooling (see Fernández Enguita, 1999; San Román, 1996; or Torres Santomé, 1992 on this point).

For their part, immigrant students are also adversely affected by the concerted school system. As a case in point, in Catalonia, the children of an immigrant family of Islamic faith were recently enrolled by education authorities in a concerted Catholic school. The father complained about the placement, arguing that the school was replete with Christian icons and clergy members, and that this circumstance (among others) might understandably influence his children's faith. His children were subsequently removed and placed in separate public schools, but not without protest from one official, who claimed the Catholic school met the conditions stipulated in the Constitution and by law. What is perhaps more disconcerting, however, is the fact that the school's administrators then took umbrage at education authorities for enrolling immigrant children of various faiths in their school "without [first] requesting permission" (reported in the daily journal El Pais, 21 February 2002, p. 32).

In a parallel, yet more complex incident involving the aforementioned Moroccan teenager and her hijab, she was initially placed at a concerted Catholic school, where her scarf was prohibited for its religious associations. But when she was subsequently enrolled in a public secondary school, the objections to her hijab there were quite different: the school principal (or headmistress) claimed in a televised news segment that it constituted a sexist imposition that 
limited the girl's freedom of self expression. In this same report, however, the principal was not shown to censure any sexism in the dominant aesthetics of other students at the school. Eventually, ideologically conservative education authorities ruled that public school professionals would be held in contempt of law if they continued to discriminate, but neither the Catholic school's personnel nor the concerted school system were otherwise affected by this resolution. This outcome, however, did not escape protest from public school educators (as reported in the daily journal La Voz de Galicia, 19 February 2002, p 26).

Nonetheless, in both incidents, the status quo of Catholic hegemony in the legal discourse on schooling remained uncontested, while the Islamic students' religious rights were treated, once again, on a contingent basis. Cultural othering was clearly at work in this and the former conflict - disputes in which the concerted school plan played an important, albeit non-exclusive, role. There were also competing cultural priorities present: Islam vs. Catholicism, secularism vs. parochialism, and, in the case of the hijab, feminist principles on equal rights. Thus, "nonsynchronous" (McCarthy, 1990) cultural dynamics were at work in these conflicts. That is, rival, and often contradictory ideologies were manifest as much through acts of discrimination (injustice) as through their proposed solutions (or "justice"). Such real-life dilemmas and contradictions - concerning not only religious doctrine in schooling or school choice, but also linguistic diversity, tolerance, compensation, and myriad others - realistically complicate the pursuit of the egalitarian educational values and practices inscribed in the LOGSE's discourse.

In short, these cultural "shades of gray", or disruptive spaces of nonsynchronous dynamics, are what pose some of the greatest challenges to the pursuit of justice through the politics of representation. Still, it is precisely the disruptive quality of these dynamics that may also offer the greatest hope for transforming dominant narratives. Before addressing that 
potential, however, these issues must first be addressed within the current political context of conservative leadership in Spain as well, and within the ideological directions that dominant discourse around reform has now taken.

\section{The "Counter-Reform"}

Since 1996, the right-wing Popular Party has occupied a majority of seats in Spanish Parliament. Their executive administrators and legislators have thus managed to launch the current counterreform without major obstacles, and via the neoconservative discursive universe of "the culture of effort", as well as the neoliberal privileging of "quality", "flexibility" and "choice" In addition to several new decrees on "Minimum Instruction" (for the Statewide base-curriculum), as well as some recent laws affecting both vocational and higher education, conservative legislators recently approved the aforementioned Quality in Education Act — a highly contested reform which has overturned many of the precedents set in the LOGSE.

One of the most controversial policies introduced with this new law is the replacement of comprehensive learning through age sixteen, with the segregation of younger students into various streams, tracks and programs. For example, all students aged fourteen will have to "choose" one of two streams: the "scientific-humanistic" or the "technological" — the former oriented toward higher learning and the latter toward vocational education. The following year, these two tracks become three (scientific, humanistic and technological), but those students whose academic performance does not meet grade level by age fifteen will be encouraged to enter a fourth, less visible track: the "Professional Initiation Program", premised on the discontinuation of schooling after age sixteen. Furthermore, some grade-level retentions that had been eliminated with the LOGSE have been reinstated, and certain "support measures" will be 
created for students ages twelve to thirteen "having special difficulties in specific areas of knowledge". ${ }^{10}$ Unfortunately, it is also within these special-grouping terms that a precedent is set: for the first time in a basic education law, immigrant students are explicitly addressed. That is, the Quality in Education Act states that:

(...) For those students unfamiliar with the Spanish language and culture, or who present grave deficiencies in basic knowledge, the educational Administrations will develop specific learning programs in order to facilitate their integration into the corresponding grade level. (Article 39; emphases added)

While all these measures are intentionally foregrounded in terms of systemic adaptability through "individualized learning", "choice" and "flexibility", the Minister's team of lawmakers have, in so doing, simultaneously backgrounded the important concerns of equity and justice. Not only does this discourse present immigrant students as deficient and as a problem for the system, but it seems to disregard what numerous international scholars have referred to as the segregational implications of both tracking and retentions in compulsory education, especially where subaltern groups are concerned (see McCarthy, 1990 for a critical overview of the most noteworthy of these). These measures further pose a serious threat to the incipient, albeit precarious, secondary school attendance experienced by Gypsy youth since the implementation of the LOGSE's Compulsory Secondary Education in 1998.

Where privatization is concerned, the Quality in Education Act extends the concerted school regime into pre-compulsory Early Childhood Education. The school offering will therefore be limited not only to the availability of such centers, but to their ideological persuasions as well. Which brings us back to the issue of religion. Catholic Religion class will remain an elective, but will compete with a proposed alternative subject containing only some of what are currently the LOGSE's "transversal" themes on ethics and democratic values. Such themes may therefore no longer be taught in a cross-curricular manner, and students learning the 
values taught in Catholic Religion class may not necessarily be exposed to the democratic values taught in the alternative "Society, Culture and Religion" class. Moreover, the availability of this latter subject may prove limited: When asked about the conditions necessary for offering the subject at each school, the Minister of Education has been quoted as replying, "That depends on the number of students because it's a bit complicated if only one or two choose it" (El Pais, 9 May 2002, p. 29).

While numerous other changes have been introduced with this law, some related legislation on curricular reform also merits attention. Namely, one of a series of Royal Decrees approved during the same administration ${ }^{11}$ has now extended the instructional time designated for language arts in Compulsory Secondary Education in order to accommodate a bolstering of the Castilian language arts over others. In addition, it has broken down the subject of History into more detailed and controlled chronological units that emphasize the history of the Spanish monarchies and central State, as opposed to that of its "peripheral" national perspectives (i.e. those of the Autonomous Communities). This maneuver is in part justified, however, through a discourse that might give the unwitting reader the opposite impression:

In History, it is expected that the students (...) identify and locate in time and space the relevant processes and events, without losing sight, however, of the common and the plural in the History of Spain, with its nationalities and regions as part of its heritage and richness (Real Decreto 3473/2000; in Boletín del Estado (BOE), no. 14, 16 January 2001, p. 1817).

In reality, these reforms are examples of a multiple-sited intensification of revisionist, linguistic, doctrinal and mercantilistic controls over the culture of schooling. Indeed, they are the tools of a defensive, conservative reaction to an increasingly multicultural reality in Spain.

Whether such a reality, at the present historic conjuncture, is increasingly crosscultural as well is a key question which requires closer attention to broader processes. This is so because the 
cultural conservatism outlined above - or centripetal force - coexists with the centrifugal forces of economic and cultural globalization. One may pose the question, then, as to whether any of the crosscultural influence from globalization might in some way serve to disrupt the kind of cultural othering that is implicit in the LOGSE, but intensified in the Quality in Education Act.

\section{$\underline{\text { Resentment, Fortress Europe, and the Cultural Other }}$}

Some of the arguments presented in Morley and Robin's (1995) book, Spaces of Identity, will help to situate this concern. They underscore the dialectical nature of the global/local nexus and its tendency to erode the nation-state as the traditional and powerful point of cultural reference and identity in Europe. The European Union, as a transnational project, embodies this trend, with all its associated contradictions: As the European "Community" grows, so too do the calls for heritage, tradition and local identity. For example, nationalist movements both peaceful and violent have emerged in some nations whose predominant sense of identity has coalesced primarily around linguistic practices historically subordinated to dominant state languages, and around long-repressed struggles for self-determination. Such is the case of the Balkan States, Northern Ireland, and several of the Autonomous Communities of Spain ${ }^{12}$ However, other calls to tradition and heritage culture respond, ironically, to the economic demands of global enterprise, with its novel need for local "niche" markets. The "quaint", the "unique" or the "original" are thus increasingly marketed by local municipalities and regions throughout Europe. This economic trend in turn influences local and national political and cultural priorities.

Finally, some of the most threatening of calls to tradition involve movements both isolated and popular promoting idealized and rigid conceptions of supposedly pure ethno-national origins, as in the political agendas of Haider in Austria or Le Pen in France. These movements 
target immigrants, Gypsies, and other sociocultural groups as racialized and/or stigmatized Others and outcasts, while harboring xenophobic sentiments within what Morley and Robin (1995) refer to as "Heimat", or a "Homeland" imaginary (one not unfamiliar on the other side of the Atlantic as well). Rising neo-Nazi activity in Spain further attests to this disturbing reality, as some of the earlier-cited conflicts in Catalonia and Andalusia attest to. But these are only the most extreme versions of an otherwise pervasive reality.

Postcolonial scholars Cameron McCarthy and Greg Dimitriadis (2000) argue that popular representations of racial and ethnic difference in the West - especially as reproduced and "simulated" through the mass media — are overwhelmingly premised on "resentment", a notion taken from Nietzsche that characterizes the process of identity formation through the negation or rejection of the culturally stigmatized Other. According to McCarthy \& Dimitriadis (2000, pp. 76-79), resentment is reproduced through four main discursive channels: those pertaining to origins, nations, popular memory and history, and media culture We have witnessed most of these discourses at work in the two laws reviewed above, especially in the counter-reform. The Quality in Education Act not only directly identifies a subordinated Other; it does so in terms of this figure's contrast to, and deficiency vis-à-vis, an ideal cultural subject. By contrast, this latter student-type is erected upon carefully selected, reworked, and reinforced narratives on origins, nation and history. In the LOGSE, however, such resentment is less pronounced, although attention to the educational needs of specific oppressed groups who transcend the linguistic, cultural and territorial orientations of this law, is, as earlier noted, absent from its discourse on cultural origins, nations and history. Granted, the shadow of such groups is indirectly perceptible through additional LOGSE discourse on solidarity, tolerance, equality, compensation, and related notions, even as these ideals are undermined by the aforementioned omissions and 
contradictions.

Such resentment has, moreover, emerged from a socio-political context in Spain that is progressively conditioned — and thereby "threatened", inasmuch as specific political and economic sectors are concerned ${ }^{13}$ - by the global/local crosscultural nexus. But the current gatekeeping reactions in Spain are indeed also occurring at the transnational level: In October of 2002, for example, the Commission to the European Council in Brussels issued the official report, "Communication from the Commission to the Council and the European Parliament on a Community Return Policy on Illegal Residents". ${ }^{14}$ It is through this emergent space of Eurocentric identity formation — or "Fortress Europe", to borrow yet another telling term from Morley and Robin (1995) — that one of the most powerful representations of the cultural Other is produced. And it may come as no surprise that this Other is embodied primarily through poor immigrants from the developing world, who are, above all, observers of Islam (Morley \& Robin, 1995).

This fortification of Europe is nonetheless simultaneously challenged by globalizing capitalists themselves. Globalization has, for example, concurrently produced a discourse of market logics with heavy demands for the cheap labor forces obtained from the flow of poor immigrants "into" Europe. These demands for low-wage laborers thus leave European borders slightly open to immigration, while placing poor working populations — both migrant and settled - in both global and local competition with each other. As an inter-ethnic class issue, this process can in turn contribute to the aforementioned xenophobic reactions in traditionally more homogeneous working communities — and thus social class distinction is once again reproduced.

In these multiple, often divergent ways, crosscultural contact in Spain is clearly conditioned by 
the global/local interplay of economic, political and cultural dynamics. And as previously noted, the values performed through educational reform echo these larger forces As Olneck (2001) observes, the attainment of a curriculum that is ever more multicultural ".. is, however, mediated by contending political, institutional and ideological forces, so it is not surprising that its success in reconfiguring the symbolic order (Gusfield, 1981) is partial” (p. 343).

Moreover, globalization is but one such force that, as noted above, has exacerbated certain pre-existing forms of bias. That is, cultural discrimination, racism and classism are nothing new to the Spanish educational system, as most Roma can attest to. Consider, for example, the subtle cultural positioning present in the news headline, "Five Hundred Secondary School Students Will Receive Classes on Gypsy Culture" (as reported in the daily journal $L a$ Opinión de A Coruña, 19 June 2002, p.8). To begin with, the fact that this event is considered a newsworthy item is doubly telling: it at once exposes the historic, hidden curriculum of omission of the Roma people and their culture from dominant narratives on schooling, while it reveals a growing mainstream interest in addressing "Gypsy Culture." The motives behind this latter development are intriguing because they may in part constitute a side-effect from globalization, among other causes. Global forces come into play here when the expanding multicultural presence of immigrants, for instance, or when new flows of information, create heightened levels of consciousness about old forms of discrimination But a second and perhaps more important observation is that, with this headline, one is hard-pressed to perceive of Roma youth as included amongst these "Students." Rather, might not this headline suggest that there is an assumed, dominant or default cultural ideal-type ("Students") that — in an "us-them" binarism — is brought into exceptional contact with the cultural Other ("Gypsy Culture")?

These omnipresent discourses of resentment (this last case reflecting that of the media 
culture) must thus be uncovered before they can be disrupted. The fact is that most of the dominant ideological perspectives upon which most curriculum questions are debated remain undisclosed and, therefore, uncontested (Carr, 1998). According to Carr (1998), Apple (1996), Popkewitz (1991), and other scholars, this is the major stability factor in educational reform as a political act. And as we have observed in the LOGSE, but especially in the Quality in Education Act, both cultural resentment and bourgeois privilege exert their combined "ideological effect" on the discourse of reform. They undermine the most "progressive" of top-down reforms (in the LOGSE itself), and they perpetuate the marginalization of students who need the very best of educational institutions. These students, as well as their mainstream peers, are thus limited in their exposure and contribution to alternative crosscultural perspectives and dynamics that transcend the hegemonic interests of the world's (and Spain's) economic and cultural elite.

\section{Situating the Ideological Effect of Reform Discourse}

On May 31, 2002, in the wake of the Minister of Education's announcement on the role of Catholic Religion in the Quality in Education bill, a news headline reads, "Muslim Spaniards Turn to Justice Courts to Demand Religion Teachers for 42,000 Children” (El País, p. 30). This class-action suit, representing at least 400,000 plaintiffs, is described as a direct challenge to the State, and is based on a reportedly systematic paucity of instructors of Islam in the schools.

In ways similar to the case of the Muslim father who contested the placement of his children in the Catholic concerted school, this strategic defense of religious rights constitutes a plea for cultural recognition, as well as a significant act of resistance to Vatican hegemony in Spanish schooling. Nonetheless, what are the chances that this kind of "war of maneuver" (to borrow a Gramscian concept) for the equal treatment of a cultural particularism (Islam) 
contribute to a crosscultural reality, as opposed to a "separate but equal" cultural pluralism in Spanish society? Can it eventually disrupt the ideological effect of dominant Catholic enculturation in education? Indeed, it runs the risk of ultimately failing to transcend the powerful discourse of resentment affecting numerous ethnic groups, as its effects are limited to the specific needs of a particular group. Seen from a nonsynchronous point of view, the "solution" embodied in the above lawsuit falls short of addressing the needs of culturally Islamic, Judaic, Christian or other religious and/or ethnic groups who desire completely secular public schooling in Spain.

Moreover, when such cultural resentment combines with class bias, crosscultural justice becomes even less attainable. As McCarthy \& Dimitriadis (2000, p. 76) have further argued, "[p]roponents of Eurocentrism and Afrocentrism are themselves proxies for larger impulses and desires for stability among the middle classes...". It is therefore not only cultural resentment, but this class-related stability factor that needs to be disrupted in the stable "eye of the hurricane" (Cuban, 1993) of passing reforms. As James Ladwig (2000) reminds us about transnational tendencies in the curricula of world educational institutions: "As part of the now global bureaucratic state mechanisms, any attempt to address multiple cultures will face the amazingly stable institutionalized dispositions of schooling" (pp. 64-65), which, he further argues, are unequivocally implicated in the reproduction of social inequality worldwide.

If our aim is to de-center these enduring forms of bias, then it is of paramount importance to search for ways to approach institutional — and thus educational — innovation that allow for the dissemination of meanings that diverge from, and deconstruct, dominant narratives on progress and reform (Rodríguez Romero, 2000). The LOGSE's reliance on a progressive narrative of "solidarity", "equality", and the like is counteracted by an underlying hidden curriculum embodied in "la cultura", in linguistic priorities, and in compensatory education, as 
well as in neoliberal arrangements such as concerted schools. The Quality in Education Act, on the other hand, is much more transparent in its investment in middle class, Castilian and Catholic cultural values, and this is so despite its misleading deployment of value-laden terminology: It indulges in a consumer-based discourse on "choice", "quality" and "the culture of effort"; it strengthens privatization (by extending concerted schooling through Early Childhood Education); and it embraces regressive policies such as tracking students at a younger age, permitting more retentions, or tightening centripetal controls over language, history and religion in the curriculum.

\section{Conclusion: Disrupting the Discourse of Reform}

In light of these biases in the discourse of reform, what will schooling look like in an ever more multicultural Spain? How will cultural conflicts of the kind described above (and in Barakaldo, Catalonia, Andalusia and Ceuta) be resolved at school and beyond? Who will define curricular content, whose languages will be used in the process, and whose system of representation will result from such "classification struggles" (Olneck, 2001)? Will some groups of students continue to experience more academic failure than others as a result? These interrogatives convey the urgency of the situation for all students, not merely for those who are over-represented in accounts of academic failure. For it is through the interaction of all groups and their mutual participation in society that positive change may occur. Among other efforts, more attention must be paid to nonsynchronous dynamics both disruptive and stable in the discursive representation of the culture of schooling. Demanding the recognition of cultural exceptionalisms (or classifications) is not enough, as other more universal principles may be overlooked in the process - especially those related to social justice, crosscultural understanding, and fair access 
to (or redistribution of) a decent standard of living for all members of society (Fraser, 1995).

Future analyses of this ideological struggle — one which both permeates and transcends the sphere of education - may stand to benefit from Seyla Benhabib's (1992) discourse ethics, or "interactive universalism". In an attempt to reconcile Habermasian universal moral principles with culturally relative values in communication — and here Benhabib is particularly interested in feminist values, which indeed figure into the case of the hijab - a pivotal notion in her communicative ethics is the idea that practical reason itself has both culturally relative and culturally transcendent (universal) components. So it is that, within the normative - albeit culturally contestable — framework of interactive universalism, public participants negotiate the meaning of diverse human rights and the collective good, as well as the norms by which they are to be debated, and the means by which they are to be applied. Benhabib approaches this procedural ethics in light of what she terms "enlarged thought" — a moral claim on impartiality as a universal regulative principle:

Enlarged thought, which morally obligates us to to think from the standpoint of everyone else, politically requires the creation of institutions and practices whereby the voice and the perspective of others, often unknown to us, can become expressed in their own right (Benhabib, 1992, p. 140).

Moreover, enlarged thought is enhanced through an expanded definition of the public sphere as "a dispersed network of many publics" (Benhabib, 1996, p. 83) The establishment of this important link between the myriad discourses of loosely associated collectives and those of the social institutions (both private and public), may thus prove more conducive to generating diverse "voice" or representing multiple views that challenge the dominant multicultural and elite crosscultural narratives so prevalent in policy today.

A key question at this point, then, is how to develop enlarged thought and interactive universalism in the context of the cultural politics around educational institutions and their 
publics. Bennett (1992) has argued that the role of policy-making institutions in defining, producing and regulating culture has been significantly overlooked and underestimated in cultural studies. We as educators must therefore help mobilize cultural strategies that influence the various "regions" of cultural production in education, of which is policy-making is an important part. One way is to call on educators at all levels to network with students, community representatives, advocacy groups, other educators, and social agents in order to produce pedagogical narratives that "perform" (Giroux, 1997) communicative ethics such as Benhabib's, that disrupt hegemonic forms of institutional stability in educational reform. These stability factors include: representations of the cultural Other via omission, tolerance or deficit; segregational classifications; undisclosed ideologies and pseudo-"truths"; institutionalized forms of resentment; etc. Another strategy would involve discursively promoting other forms of stability worth investing in, such as the conditions necessary for achieving sociocultural justice through schooling - especially when such conditions may already be in place, but are compromised by budget cuts or other institutional measures (Apple, 1996). In Spain, this would generally entail mobilizing to impede the progressive encroachment, by the private sector (through concerted schools and other schemes), into what has long been upheld as a public right: a basic schooling (Torres Santomé, 2001). This task indeed represents nothing short of a social movement commited to social justice and to the reinstatement of person rights over property rights.

Beyond these broader strategies, much work should also be initiated more directly from within school settings. As John Dewey (1916) underscored, schools themselves must become democratically organized if they are to foster deeper democratic participation in society. For that matter, the availability of more collectively-authored books grounded in school-based democratic 
participation — such as Democratic Schools (Apple \& Beane, 1997), or Dilemmas of Reform (Kemmis, et al., 1987) — would help pave the way. Whereas the former of these works documents how deeper democratic approaches to public deliberation, social justice and community intervention were developed through "bottom-up", or local, educational designs and practices at four US schools, the latter details the mixed outcomes of the Participation and Equity Program in the schools of Victoria, Australia. In this latter case, the reform transcended the localschool level, and the authors note the connections and tensions between good intentions, bureaucratic obstacles, and shifting political tides. Returning to Spain, an important participatory victory gained in the $1980 \mathrm{~s}$ - that of elected school-community members voting on key schoolpolicy issues - has in fact also been revoked with the Quality in Education Act. And yet, this is only one more consequence of the particularly virulent resentment currently affecting educational and social policy discourse in general in Spain.

Clearly, the cultural stakes of such policy decisions are high for collectives who are already marginalized according to language, ethnicity, race, gender or social class in Spanish society. Fortunately, ever more Spanish-State educators and social agents - several of whom have been referred to throughout this essay — are developing community approaches to educational participation and change that are at once critical, crosscultural, interdisciplinary, and/or plurilingual, and that parallel work from international scholars on similar issues. In addition to the critical scholarship reviewed in these pages, we should also take note of Sonia Nieto's (2002) insights on crosscultural teacher education; Christine Sleeter's (1996) perspectives on multicultural education as social activism; Joe Kincheloe and Shirley Steinberg's (1998) views on critical teaching strategies; and Freire's prolific work on emancipatory pedagogies (see, e.g., Freire, 2001). By approaching such pedagogies as a collective effort, we 
may just help bridge the gap between the theory and the actual practice of promoting the place of subaltern voices, hybrid identities and counter-narratives in the "culture of discourse" on educational reform.

\section{References}

Angulo Rasco, F. (1995). El neoliberalismo o el surgimiento del mercado educativo. Kikirikí, 35, 25-33. Apple, M. (1996). Cultural Politics and Education. New York: Teachers College / Columbia University. Apple, M. W., \& Beane, J. A. (Eds.) (1997). Democratic Schools Alexandria, Virginia: Association for Supervision and Curriculum Development.

Asociación Presencia Gitana (1991). Los gitanos ante la ley y la administración. Madrid: Editorial Presencia Gitana (Editorial Asidiajú Callí).

Asociación Secretariado General Gitano (2000). Unpublished lecture presented at the conference "Social Services and Intervention with the Gypsy Population: Access to Normalized Resources" (10-11 November), in A Coruña, Spain.

Benhabib, S. (1992). Situating the Self: Gender, Community and Postmodernism in Contemporary Ethics. New York: Routledge.

Benhabib, S. (1996). Toward a Deliberative Model of Democratic Legitimacy. In S. Benhabib (Ed.): Democracy and Difference: Contesting the Boundaries of the Political (pp. 67-94). Princeton: Princeton University Press.

Bennett, T. (1992). Putting Policy into Cultural Studies. In L. Grossberg, C. Nelson \& P. Treichler (Eds.): Cultural Studies (pp. 23-37). New York: Routledge.

Bernstein, B. (2000). Pedagogy, Symbolic Control and Identity: Theory, Research, Critique. New York: Rowman \& Littlefield.

Bhabha, H. (1994). The Location of Culture. London: Routledge.

Blommaert, J., \& Verschueren, J. (1998). Debating Diversity: Analysing the Discourse of Tolerance. London: Routledge.

Bueno Aguilar, J. J. (1993). El lenguaje de los niños gitanos: una perspectiva funcional. Salamanca: Amarú Ediciones.

Calvo Buezas, T. (2000). Inmigración y racismo: así sienten los jóvenes del siglo XXI. Madrid: Cauce.

Carr, W. (1998). The Curriculum in and for a Democratic Society. Curriculum Studies 6(3), 323-340.

Connell, R. W. (1993). Schools and Social Justice. Philadelphia: Temple University Press.

Courthiade, M. (1998). Estructura dialectal de la lengua romaní. Interface (31), 9-14.

Cuban, L. (1993). How Teachers Taught: Constancy and Change in American Classrooms, 1890-1990. New York: Teachers College Press.

De Lucas, J., \& Torres, F. (Eds.) (2002). Immigrantes: ¿Cómo los tenemos? Algunos desafíos y malas respuestas. Madrid: Talasa.

Dewey, J. (1916). Democracy and Education. New York: The Free Press.

Eisner, E. W. (1992). Educational Reform and the Ecology of Schooling. Teachers College Record, 93(4), 610-621.

Fernández Enguita, M. F. (1999). Alumnos gitanos en la escuela paya: un estudio sobre las relaciones étnicas en el sistema educativo. Barcelona: Ariel Praticum.

Franzé Mudanó, A., \& Mijares Molina, L. (Eds.) (1999). Lengua y cultura de origen: niños marroquies en 
la escuela española (Taller de Estudios Internacionales Mediterráneos). Guadarrama, Madrid: Ediciones del Oriente y del Mediterráneo.

Fraser, N. (1995). From Redistribution to Recognition? Dilemmas of Justice in "Post-Socialist" Age. New Left Review (212), 68-93.

Freire, P. (2001). Pedagogía de la indignación. Madrid: Morata.

Fresno García, J. M. (1994). Evaluación del la incorporación de los niños y niñas gitanos en la enseñanza básica (Unpublished Report). Madrid: CIDE (Centro de Investigación y Documentación Educativa) / Ministerio de Educación y Ciencia.

Fundación Hogar del Empleado (Ed.). (2000). Informe Educativo 2000: evaluación de la LOGSE. Madrid: Santillana.

García Castaño, F. J., Granados Martínez, A., \& García-Cano Torrico, M. (1999). De la educación multicultural e intercultural a la lengua y cultura de origen: reflexiones sobre el caso español. In F.J. García Castaño \& A. Granados Martínez (Eds.): Lecturas para educación intercultural (pp. 81-128). Madrid: Trotta.

Giroux, H. A. (1997). Is There a Place for Cultural Studies in Colleges of Education? In H.A. Giroux \& P. Shannon (Eds.): Education and Cultural Studies: Toward a Perfomative Practice (pp. 231-247). London: Routledge.

Gómez Llorente, L. (2000). Educación pública. Madrid: Morata.

Hall, S. (1996). On Postmodernism and Articulation: An Interview with Stuart Hall [Edited by Lawrence Grossberg]. In D. Morley \& K.-H. Chen (Eds.), Stuart Hall: Critical Dialogues in Cultural Studies (pp. 131-150). London: Routledge.

Hall, S. (1992). Our Mongrel Selves. New Statesman \& New Society, 121/88(4089/1530), 6 ("Borderlands" supplement).

Jover, G. \& Reyero, D. (2000, Fall). Images of the Other in Childhood: Researching the Limits of Cultural Diversity in Education from the Standpoint of New Anthropological Methodologies. Encounters on Education, $1 . \quad$ Retrieved from: http://educ.queensu.ca/ eoe/pages/issue 1/encounters_resumen.html.

Juliano, D. (1993). Educación Intercultural: escuela y minorías étnicas. Madrid: Eudema / Ediciones de la Universidad Complutense.

Kemmis, S., Rizvi, F., Walker, R., Fisher, J., \& Parker, Y. (1987). Dilemmas of Reform: An Overview of Issues and Achievements of the Participation and Equity Program in Victorian Schools 19841986 Victoria (Australia): Deakin Institute for Studies in Education (DISE), Deakin University.

Kincheloe, J. L., \& Steinberg, S. R. (Eds.) (1998). Unauthorized Methods: Strategies for Critical Teaching. New York: Routledge.

Ladwig, J. G. (2000). World Institutions, World Dispositions: Curriculum in the World-Cultural Institution of Schooling. In R. Mahalingam \& C. McCarthy (Eds.): Multicultural Curriculum: New Directions for Social Theory, Practice, and Policy (pp. 56-69). New York: Routledge.

Lezcano López, F. (2000). La LOGSE y su incidencia en la enseñanza pública. In Fundación Hogar del Empleado (Ed.), Infrome Educativo 2000: evaluación de la LOGSE (pp. 243-275). Madrid: Santillana.

Liégeois, J.-P. (1998). Minoría y escolaridad: el paradigma gitano. Madrid: Centre de recherches tsiganes / Editorial Presencia Gitana.

Martínez Bonafé, J. (1998). Trabajar en la escuela: profesorado y reformas en el umbral del siglo XXI. Madrid: Miño y Dávila Editores.

McCarthy, C. (1990). Race and Curriculum: Social Inequality and the Theories and Politics of Difference in Contemporary Research on Schooling London: The Falmer Press.

McCarthy, C. (1998). The Uses of Culture: Education and the Limits of Ethnic Affiliation. New York: Routledge.

McCarthy, C., \& Dimitriadis, G. (2000). Globalizing Pedagogies: Power, Resentment, and the Renarration of Difference. In R. Mahalingham \& C. McCarthy (Eds.), Multicultural Curriculum: New Directions for Social Theory, Practice, and Policy (pp. 70-83). New York: Routledge. 
McLaren, P. (1999). Schooling as Ritual Performance: Toward a Political Economy of Educational Symbols and Gestures New York: Rowman \& Littlefield.

Morales, M. (1999). El multilingüismo como recurso didáctico en la ESO. In F. Checa \& E. Soriano (Eds.): Inmigrantes entre nosotros: trabajo, cultura y educación intercultural (pp. 275-290). Barcelona: Icaria Antrazyt.

Morley, D., \& Robin, K. (1995). Spaces of Identity: Global Media, Electronic Landscapes and Cultural Boundaries. London: Routledge.

Nieto, S. (2002). Language, Culture and Teaching: Critical Perspectives for a New Century. Mahwah, New Jersey: Lawrence Erlbaum and Associates.

Olneck, M. R. (2001). Re-Naming, Re-Imagining America: Multicultural Curriculum as Classification Struggle. Pedagogy, Culture and Society 9(3), pp. 333-354.

Perry, T., \& Delpit, L. (Eds.) (1998). The Real Ebonics Debate: Power, Language, and the Education of African-American Children Boston: Beacon Press.

Popkewitz, T. S. (1991). A Political Sociology of Educational Reform: Power/Knowledge in Teaching, Teacher Education and Research New York: Teachers College Press.

Popkewitz, T. S. (1998). Struggling for the Soul: The Politics of Schooling and the Construction of the Teacher New York: Teachers College Press.

Rodríguez Romero, M. M. (2000). Las representaciones del cambio educativo. Revista Electrónica de Investigación Educativa, 2(2). Retrieved from: http://redie.ens.uabc.mx/vol2no2/contenidoromero.html.

San Román, T. (1997). La diferencia inquietante: viejas y nuevas estrategias culturales de los gitanos. Madrid: Siglo XXI.

Skutnabb-Kangas, T. (2000). Linguistic Genocide in Education - Or Worldwide Diversity and Human Rights? Mahwah, New Jersey: Lawrence Erlbaum Associates.

Sleeter, C. (1996). Multicultural Education as Social Activism. Albany: State University of New York.

Teasley, C. (2000). Construir la atención a la diversidad en la ESO: etnografía de una realidad escolar. Aula de Innovación Educativa 95(octubre), pp. 38-41.

Torres Santomé, J. (1992). El curriculum oculto. Madrid: Morata.

Torres Santomé, J. (2001). Educación en tiempos de neoliberalismo. Madrid: Morata.

Torrione, M. (1994). El gitano-español: de la etiqueta germanesca a la catalogación lingüística (siglos XVXVIII). In L. Martín Rojo, C. Gómez Esteban, F. Arranz Lozano, \& A. Gabilondo Pujol (Eds.), Hablar y dejar hablar (sobre racismo y xenofobia). (pp. 95-112). Madrid: Universidad Autónoma de Madrid.

Varela, J., \& Álvarez-Uría, F. (1991). Arqueología de la escuela. Madrid: La Piqueta.

Williams, S. E. (1991). Classroom Use of African American Language: Educational Tool or Social Weapon? In C. E. Sleeter (Ed.), Empowerment Through Multicultural Education (pp. 199-216). Albany, New York: State University of New York.

\section{Acknowledgements}

I would like to express my gratitude to Jurjo Torres Santomé for his helpful comments on this essay.

\section{Notes}

1 "Gypsy" or "gitano(-a)" is the term used by most members of Gypsy collectives in Spain to refer to 
themselves, whereas "Roma" or "romani" has emerged of late amongst activists and scholars of both Gypsy and non-Gypsy origins, to promote an historically informed, transnational ethnic identity. Out of respect for both postures, the terms Gypsy and Roma will be employed interchangeably in this text.

${ }^{2}$ The Autonomous Communities may legislate on most civic concerns within their jurisdictions as long as such laws do not compromise central government competences. Article 3 of the Constitution, for example, establishes Castilian Spanish as both the official State language and as the duty of all citizens to learn. And whereas the Autonomous Communities may declare other historic/national Iberian languages as "coofficial" with the Castilian in schooling and in other civic institutions, it is their right, but not their duty. Article 149 of the Constitution specifies all competencies reserved for the central State government.

${ }^{3}$ The complete, Spanish-language text of the LOGSE (Ley Orgánica de Ordenación General del Sistema Educativo) is retrievable at: http://www.mec.es/inf/comoinf/e-1-4.htm .

${ }^{4}$ This reality has been recently reflected in the official report "Escolarización del alumnado de origen inmigrante en España: análisis descriptivo y estudio empírico (2003)", from the Office of the State Ombudsman of Spain. See http://www.defensordelpueblo.es/index.asp?destino=informes2.asp.

${ }^{5}$ Ethnicity is not officially accounted for in school enrollments; however, high school teachers and Roma families throughout Spain have had much to say about this recent turn of events (see Teasley, 2000).

${ }^{6}$ This figure is based on estimates from various Roma advocacy groups (see, for example, Fundación Secretariado General Gitano at: http://www.fsgg.org/default.htm ).

${ }^{7}$ The full-text version of the Quality in Education Act (Ley Orgánica de Calidad de la Educación) was retrieved from: http://www.mec.es/leycalidad/index.htm.

${ }^{8}$ Based on findings from the Global Program for the Regulation and Coordination of Foreign Status and Immigration in Spain (GRECO) which, in the year 2000, identified immigrants of Moroccan origins as the most numerous non-European group (as reported in El Pais, 4 December 2000, p. 18).

9 There is as yet a paucity of studies on this phenomenon; however, the 2003 State Ombudsman's report cited above (see endnote 4 ) has just confirmed this tendency.

${ }^{10}$ Quoted from the promotion campaign "Cuestiones de especial interés sobre el proyecto de Ley de Calidad de la Educación", and retieved from: http://www.mec.es/leycalidad/index.htm .

${ }^{11}$ Real Decreto 3473/2000. See the Boletin del Estado (BOE), no. 14, January 16, 2001, p. 1817.

12 Consider, for instance, two very different struggles for self-determination in the Basque Country: that of the majority nationalist party (PNV), and that of the criminal organization ETA.

13 The Quality in Education Act was promoted in tandem with the latest immigration law (LO 4/2000), which has tightened penalties and restricted the rights of undocumented residents in Spain. It is considered by some to be imcompatible with the State Constitution and with international law on human rights (see de Lucas \& Torres, 2002).

14 The European Union's on-line "Legislation in Preparation" information service (at http://www.europa.eu.int/eur-lex/en/com/greffe index.html) offers the full document in pdf format. 